\title{
Local Working Requirement on Patens Policy for Pharmaceutical Products and Its Relation to Right in Public Health
}

\author{
Kholis Roisah $^{1}$, Rahayu $^{2}$, Darminto $^{3}$, Leony Sondang Suryani ${ }^{4}$ \\ \{r_kholis@yahoo.com ${ }^{1}$, rahayu_undip@yahoo.com ${ }^{2}$, darmintohartono@gmail.com ${ }^{3}$, \\ leonysondang@gmail.com ${ }^{4}$ \} \\ Universitas Diponegoro, Indonesia ${ }^{1,2,3,4}$
}

\begin{abstract}
Local Working Requirements (LWR) regulation in the 2016 Patent Law amended through Article 107 of Job Creation Law by elimination a requirements of technology transfer, absorption of investment, and employment. Besides that, it also adds provisions that are categorized as LWR, namely importing or implementing product or patent process licenses which can give an impact specially in the access of public health rights because it can cause medicine price high. The type of legal research used is nondoctrinal and the approach method used in this research normative juridical method by reviewing legal principles and doctrine of intellectual property rights and the provisions of national and international law regulations in the field of intellectual property rights law and health law that are enforced in Indonesia. This research found that the change of LWR regulation will have an impact on the abuse of patent rights in the form of patent blocking, which the registration of pharmaceutical patents whose purpose is only to prevent others from trading products whose technology is requested for protection and in the end can obstructing public access to cheap drugs and further hampering the independence of the pharmaceutical industry.
\end{abstract}

Keywords: Patents, Local Working Requirements, Public Health

\section{Introduction}

National development basically has an important and strategic meaning for Indonesia, which is aimed to improve all aspects of the life and in the same time is also a process of developing the whole state administration system. This national development effort is a manifestation of the goals of the Indonesian state as set out in the fourth paragraph of the preamble to the 1945 Constitution of the Republic of Indonesia (UUD NRI 1945) which states:

“... Pursuant to which, in order to form a Government of the State of Indonesia that shall protect the whole people of Indonesia and the entire homeland of Indonesia, and in order to advance general prosperity, to develop the nation's intellectual life, and to contribute to the implementation of a world order based on freedom, lasting peace and social justice...".

So that it can be clearly stated that the main goal to be achieved by the Indonesia is to create social justice for all people through the social service state service which is realized through 
development and improvement of welfare through giving a more important role to the state in providing social services to its citizens.

Furthermore, the existence of the Indonesian as a welfare state is also regulated in Article 1 paragraph (3) of the UUD NRI 1945 which state "The State of Indonesia shall be a state based on the rule of law". This means, as a consequence of the existence of Indonesia as a rule of law, everything should be done based on the law which makes the law must also be able to meet human needs [1]. The concept of the Welfare State (welvaartsstaat) adopted by Indonesia is the concept of a welfare state which requires the existence of regulations to be carried out by the government in an effort to realize the welfare itself where the position of the state which was previously limited to maintaining order is then expanded by giving more authority to the country to regulate the economy sector [2]. The consequence of this expansion of authority then makes the public interest as the principle of public law no longer interpreted as the interest of the state as the power that maintains order or the interests of the bourgeoisie as the basis of society of a liberal law state, but is interpreted as the interest of "gedemocratiseerde nationale staat, waarvan het hele. volk in al zijn geledin gen deel uitmaakt" which means that all people at all levels are part of the state [3].

This is also supported by Utrecht's opinion that in a modern constitutional state, the government has a very wide field of work, that is to maintain security which means as all field of social security [4]. This means that in Indonesia, the government is expected to role the economic and social life of the community in addition to maintaining order and security (rust en orde) [5]. The role of the state in the concept of a welfare state formulated in the preamble of the UUD NRI 1945 which became the basis of thought for the founding fathers of Indonesia where by Moh. Hatta stated that the UUD NRI 1945 contains the spirit towards the formation of a welfare state model with the objectives to be achieved, namely. First, to control and utilize socio-economic resources for the public interest. Second, to ensure a fair and equitable distribution of wealth. Third, to reduce poverty. Fourth, to provide social insurance (education and health) for the poor. Fifth, to provide subsidies for basic social services for disadvantage people. Sixth, to provide social protection for every citizen [5].

One of the state role in creating the prosperity and welfare of the people is through the economic sector which has been strictly regulated in Article 33 of the UUD NRI 1945 which is a constitutional foundation for regulating the national economy as an economic foundation characterized by economic democracy. The economic system applied in Indonesia is the Pancasila economic system, which contains economic democracy, which means economic activities are carried out from, by, and for the people under the supervision of the government as a result of the popular elections. The economic democratic system gives meaning to the control of the assets of the source of economic strength, business fields that control the lives of the people and are controlled by the state, to keep the people from being under the control of individuals who control the production branches for the main interests and needs of the community.

One of the fields in human life that is regulated by the state is invention as a form of human intellectual creativity. An invention itself can become a patent right if it meets the requirements, including novelty, inventive step and industrial application, which means that the invention can be implemented or produced on an industrial scale. Thus, when the invention is turned into a patent right [6], an exclusive right will emerge for the owner which then creates an obligation that must be carried out by the patent owner to produce the invention in the country of origin of the patent itself and/or in other countries where the invention is registered as a patent right [7].

One of the inventions that can be registered as a patent is medicine. Basically, one of the objectives of patent registration for drugs is to ensure that the costs of research and development 
of drugs required by drug manufacturers will be covered for the duration of the patent protection period (minimum twenty years). This is because with the exclusive rights arising from patents, at least during the term of the patent protection, the producers or patent holders of these drugs have the right to produce, distribute, exploit economically and prohibit third parties who are not authorized to produce drugs [8]. Regarding this purpose, developing countries including Indonesia have implemented the Local Working Requirements (LWR) which is a policy aim to improve a further dissemination and development of technology and to create an employment in the country. The LWR policy itself is adopted by Indonesia in its Patent Law, starting from Law number 6 of 1989 regarding Patents to Law number 13 of 2016 concerning Patents (Patent Law). This policy stated in article 20 of the Patent Law which states:

(1) Patent holders are required to manufacture products or use processes in Indonesia.

(2) Making a product or using a process as intended in paragraph (1) must support technology transfer, absorption of investment and/or provision of job opportunities.

However, the policy regarding LWR in Patents Law then has been changed by Law of the Republic of Indonesia No. 11 of 2020 on Job Creation (Job Creation Law) by adds a provisions that are categorized as LWR, namely importing or implementing product or patent process licenses which can give an impact specially in the access of public health rights because it can causes medicine price high.

\section{Research Method}

Research method for researchers is a way to find, analyze a particular problem to find a truth. Because the research method is a guide for scientists to study, analyze and understand the problem. This is why research method is an element that absolutely must be present in scientific research and development. The type of legal research used is non-doctrinal. In non-doctrinal legal research, law is conceptualized as a manifestation of the symbolic meanings of social actors as seen in their interactions. The approach method used in this research normative juridical method. The juridical aspect lies in the use of legal principles and principles in reviewing, especially legal principles or principles of law and the doctrine of intellectual property rights, especially patent law, to view and analyze patent application requirements. Meanwhile, from a normative perspective, this research is a reference used by researchers to analyze existing problems, namely the provisions of national and international law regulations in the field of intellectual property rights law and health law that are enforced in Indonesia [8].

Method of collecting data is done by collecting laws and regulations, books, literature, and expert writings related to the object of the study. Furthermore, data analysis in this study uses qualitative methods, namely the selection of data obtained from research based on quality or quality so that a relevant description is produced that can answer questions in existing problems clearly and completely based on library research and then arranged systematically in order to obtain conclusion.

\subsection{Implementation of LWR in Indonesia}

Patents rise an exclusive rights for their owners [6] for a certain period of time to carry out their own inventions or to give their consent to other parties to carry them out. This exclusive right then creates an obligation that must be carried out by the patent owner to produce the invention in the country of origin of the patent itself and/or in other countries where the 
invention is registered as a patent right [7]. In this case, especially for developing countries LWR is useful for the spread and further development of technology, technology transfer, create employment, increasing industrial capacity, balance of payments and economic independence [9]. If this obligation is not fulfilled, there is a possibility that the patent will be canceled [10] or there will be an implementation of a compulsory license [11].

In essence, LWR aims to make a new product inventions economically empower for patent owners [12], and for users to obtain new, better and more sophisticated products. This also applies to pharmaceutical product patents, so that with LWR, patent owners can immediately benefit economically [13] which comes from compensation for research costs that take a long time and are expensive to produce new drug inventions and for the public can get access to new nutritious drugs [14].

Basically, in the Indonesia patent law system, the LWR has begun to be regulated in Law number 6 of 1989 concerning Patents until the lattest one is in Law number 13 of 2016 concerning Patents. LWR in the patent law system in Indonesia is a mandatory obligation, which means that the owner or patent holder has the special right to carry out his patent company independently or by giving approval to others, to make, sell, rent, submit, use, provide for sale or rent or delivery of products that are patented and the holder also has the right to use the patented production process to make goods. Patent holders have the mandatory obligation to use their patents in the territory of the Republic of Indonesia and imports of products that are patented or made using a process that are granted a patent do not constitute a patent exercise.

LWR provisions are strictly requiring a technology transfer appear in the Patent Law which state that Patent Holders are required to make products or use processes in Indonesia. The implementation of LWR must support technology transfer, absorption of investment and / or create an employment opportunities. And if there is a failure such as not implementing the LWR within 36 months or the implementation of the LWR has been detrimental to the interests of the community, according to the provisions of Article 82 of the Patent Law it is possible to have a compulsory license. Furthermore, a delay in the implementation of the LWR for more than 36 months can be filed with reasons and accompanied by written evidence and can have the implication of eliminating part or all of the patent rights through a lawsuit to the Court.

Correlation between LWR and the right to health itself can be seen from what Law Number 36 Year 2009 concerning Health (Health Law) says that the meaning of healthy is conclude physically, mentally, socially, and spiritually that allows an individual to live socially and economically. This is then confirmed by what is mandated in Article 2 of the Health Act which states "Everyone has the right to obtain safe, quality, and affordable health services". The right to health must then be seen broadly, not only the healthy condition that is felt by each individual community and group of people, but also several other stakeholders who participate in supporting the healthy condition which include the availability of access to proper medicines for the community.

\subsection{The Amendments of LWR Provisions and Its Juridical Impact}

LWR regulation in the 2016 Patent Law was later amended through Article 107 of Job Creation Law by elimination a requirements of technology transfer, absorption of investment, and employment. Besides that, it also adds provisions that are categorized as LWR, namely importing or implementing product or patent process licenses. 
Table 1. LWR in Patents Law System in Indonesia

\begin{tabular}{|c|c|c|c|c|}
\hline Indicator & Law No. 6/1989 & Law No. 13/1997 & Law No. 14/2001 & Law No. 13/2016 \\
\hline Provisions & $18,20,82,94$ & 18,82 & 18,82 & $\begin{array}{l}20,82 \text { (1.a), 90, } \\
132 \text { (1.e) }\end{array}$ \\
\hline Obligations & $\begin{array}{l}\text { Mandatory } \\
\text { without exception }\end{array}$ & $\begin{array}{l}\text { Mandatory with } \\
\text { no exceptions }\end{array}$ & $\begin{array}{l}\text { Mandatory with } \\
\text { no exceptions }\end{array}$ & $\begin{array}{l}\text { Mandatory with } \\
\text { additional } \\
\text { requirements }\end{array}$ \\
\hline Exception & & $\begin{array}{l}\text { Economic/regiona } \\
1 \text { scale } \\
\text { implementation }\end{array}$ & $\begin{array}{l}\text { Economic/regiona } \\
1 \text { scale } \\
\text { implementation }\end{array}$ & \\
\hline $\begin{array}{l}\text { Mandatory } \\
\text { License }\end{array}$ & 36 months & 36 months & 36 months & 36 months \\
\hline Penalty & $\begin{array}{l}\text { Null and void if it } \\
\text { is not } \\
\text { implemented } \\
\text { within } 46 \text { months }\end{array}$ & $\begin{array}{l}\text { There is no } \\
\text { sanctions }\end{array}$ & $\begin{array}{l}\text { There is no } \\
\text { sanctions }\end{array}$ & $\begin{array}{l}\text { Removal } \\
\text { lawsuit }\end{array}$ \\
\hline
\end{tabular}

The latest amendment to the provisions of LWR through the Job Creation Law which categorizes importing activities as part of LWR has caused a lot of criticism in the community and in academics since the beginning of the discussion of the Job Creation Bill. For the government, the implementation of regulations regarding LWR technically encountered difficulties because there were no implementing regulations. This is showed by the fact that the LWR regulation from 1989 was not implemented. In most countries the regulations on LWR are part of the national patent law system in most WTO [15] members with many variations and various national requirements which have been evolved. LWR is a legal concept that has been fought by developing countries in response to increased patent protection during the TRIPs Agreement negotiation process. The national patent systems of countries differ in providing a definition of adequate LWR and the precise territorial scope of patent creation, the circumstances in which they will tolerate the mandate period for enforcing the patent is to be enforced, and the sanctions that will be imposed on non-functioning patents. These various regulations regarding LWR implementation then did not go as well as it should be. For pharmaceutical product patents, the disruption of LWR implementation will have an implications for the disruption of drugs availability and at the same time will obstruct people's access rights to medicines.

In the same time, actually LWR for the government is deemed contrary to the TRIPs Agreement, especially Article 27 paragraph (1) TRIPs Agreement which states, patents shall be available and patent rights enjoyable without discrimination as to the place of invention, the field of technology and whether products are imported or locally produced. And it also less in accordance with the regulations in other WTO and WIPO member countries. Besides of that, the existence of this LWR article also resulted in a decline in patent applications [16].

Table 2. Patent Application Data for the last 3 (three) years

\begin{tabular}{cccc}
\hline Year & Patent & Simple Patent & PCT \\
\hline 2017 & 1,289 & 197 & 3,811 \\
2018 & 1,457 & 329 & 4,919 \\
2019 & 642 & 258 & 2,324 \\
\hline
\end{tabular}

The government's reluctance to make a policy to implement LWR, especially in the field of pharmaceutical products, is also because of the pressure from America and West Europe, 
which are countries of origin for pharmaceutical companies that control the production and distribution of world pharmaceutical production, including in Indonesia. As a result of the regulation of the LWR Article in the Patent Law, it has received objections from other countries, especially by developed countries which routinely register large amounts of patent ownership in Indonesia. Another thing that will have an impact is the imposition of reciprocal actions against patents owned by Indonesian inventors or the imposition of trade sanctions on Indonesian trade products abroad, where will have an adverse impact on the export trade of Indonesian products.

One of the countermeasures that will have an impact on Indonesian exports is the imposition of the GSP (General System of Preference) revocation by the United States. GSP is a program provided by the United States for several products that may be allowed to enter the United States market by being granted duty free by first fulfilling the stipulated requirements by Congress, including to provide reasonable access to the American market.

The objection of the United State of State Representatitive (USTR) when the deliberation of the bill in the DPR said that it is impractical to set up factories in all countries and most companies rely on sophisticated supply and distribution chains to serve their customers across all countries in the world [17]. The removal of the GSP, may possibly cause of potential losing the potential of Indonesia in export products that use the benefits of the GSP facility around \$ 2.13 billion dollars of Indonesia's total exports to the United States of $\$ 18.4$ billion dollars.

Even though the LWR provisions in Article 20 have not been abolished, the amendment by categorizing imports as a part of the implementation of patents and the elimination of the obligation to transfer technology still raises questions. Importation is basically about trade [18] whereas LWR is about to make an obligation about the product's production. The granting of exclusive rights to pharmaceutical product patents without being balanced with the implementation of pharmaceutical production and only importation will have an impact on the abuse of patent rights [19] in the form of patent blocking, which the registration of pharmaceutical patents whose purpose is only to prevent others from trading products whose technology is requested for protection and in the end can obstructing public access to cheap drugs and further hampering the independence of the pharmaceutical industry.

\section{Conclusion}

LWR aims to make a new product inventions economically empower for patent owners, and for users to obtain new, better and more sophisticated products. This also applies to pharmaceutical product patents, so that with LWR, patent owners can immediately benefit economically which comes from compensation for research costs that take a long time and are expensive to produce new drug inventions and for the public can get access to new nutritious drugs. The LWR regulation in the 2016 Patent Law was later amended through Article 107 of Job Creation Law by elimination a requirements of technology transfer, absorption of investment, and employment. Besides that, it also adds provisions that are categorized as LWR, namely importing or implementing product or patent process licenses. The granting of exclusive rights to pharmaceutical product patents without being balanced with the implementation of pharmaceutical production and only importation will have an impact on the abuse of patent rights in the form of patent blocking, which the registration of pharmaceutical patents whose purpose is only to prevent others from trading products whose technology is requested for 
protection and in the end can obstructing public access to cheap drugs and further hampering the independence of the pharmaceutical industry.

\section{References}

[1] H. McCoubrey, "Textbook on jurisprudence," 1993.

[2] A. Ilmar, Hak Menguasai Negara Dalam Privatisasi BUMN. Kencana, 2012.

[3] A. Smith, An Inquiry into the nature and causes of the Wealth of Nations... New edition, revised, corrected and improved. 1863.

[4] E. Utrecht, "Pengantar Hukum Administrasi Negara." PT. Ichtiar Baru, 1985.

[5] S. F. Marbun, "Hukum Administrasi Negara I," Fak. Huk. UII Press. Yogyakarta, 2012.

[6] G. de Rassenfosse and K. Higham, "Decentralising the patent system," Gov. Inf. Q., vol. 38, no. 2, p. 101559, 2021.

[7] M. Trimble, "Patent working requirements: Historical and comparative perspectives," UC Irvine L. Rev., vol. 6, p. 483, 2016.

[8] S. Sinaga, "Ancaman Paten terhadap Kesehatan Publik dan Safeguard Trips." Artikel Hak Kekayaan Intelektual Unika Atmajaya, 2015.

[9] M. Halewood, "Regulating patent holders: local working requirements and compulsory licences at international law," Osgoode Hall LJ, vol. 35, p. 243, 1997.

[10] H. Hovenkamp, "The Emergence of Classical American Patent Law," Ariz. L. Rev., vol. 58, p. 263, 2016.

[11] P. Champ and A. Attaran, "Patent rights and local working under WTO TRIPS agreement: An analysis of the US-Brazil patent dispute," Yale J. Int'l L., vol. 27, p. 365, 2002.

[12] A. Marsoof, "Local Working of Patents: The Perspective of Developing Countries," in Multidimensional Approaches Towards New Technology, Springer, 2018, pp. 315-337.

[13] R. Nasir, "Paten Dalam Proses Produksi: Tinjauan Hak Yang Melekat pada Inventor," J. Huk. POSITUM, vol. 1, no. 1, pp. 141-149, 2016.

[14] S. Wartini, "The Legal Implication of Compulsory Licence Pharmaceutical Products in the TRIPS Agreement to the Protection of the Right to Health in Developing Countries," J. Din. Huk., vol. 18, no. 1, pp. 1-11, 2018.

[15] T. Cottier, S. Lalani, and M. Temmerman, "Use it or lose it: Assessing the compatibility of the Paris convention and TRIPS agreement with respect to local working requirements," J. Int. Econ. Law, vol. 17, no. 2, pp. 437-471, 2014.

[16] J. H. Reichman, "Comment: compulsory licensing of patented pharmaceutical inventions: evaluating the options," J. Law, Med. Ethics, vol. 37, no. 2, pp. 247-263, 2009.

[17] Kementerinan Hukum dan HAM-Badan Pembinaan Hukum Nasional, Naskah Akademik RUU Tentang Perubahan Undang Undang Nomor 13 Tahun 2016 tentang Paten. 2016.

[18] Kliklegal, "Kisah Keberatan Kamar Dagang Amerika terhadap Pasal 20 UU Paten," Kliklegal, 2017. [Online]. Available: https://kliklegal.com/kisah-keberatan-kamar-dagang-amerikaterhadap-pasal-20-uu-paten.

[19] M. Arega, "Defending local working," Am. U. Intell. Prop. Br., vol. 10, p. 28, 2019. 